\title{
DNA repair phenotype and dietary antioxidant supplementation
}

\author{
Serena Guarnieri ${ }^{1}$, Steffen Loft ${ }^{2}$, Patrizia Riso ${ }^{1}$, Marisa Porrini ${ }^{1}$, Lotte Risom ${ }^{2}$, Henrik E. Poulsen ${ }^{3}$, \\ Lars O. Dragsted ${ }^{4}$ and Peter Møller ${ }^{2 *}$ \\ ${ }^{1}$ Department of Food Science and Microbiology, Division of Human Nutrition, University of Milan, Milan, Italy \\ ${ }^{2}$ Department of Environmental and Occupational Health, Institute of Public Health, University of Copenhagen, Copenhagen, Denmark \\ ${ }^{3}$ Department of Clinical Pharmacology, Q7642, Rigshospitalet, Copenhagen, Denmark \\ ${ }^{4}$ Department of Human Nutrition, University of Copenhagen, Copenhagen, Denmark
}

(Received 16 January 2007 - Revised 20 July 2007 - Accepted 24 August 2007 - First published online 10 October 2007)

\begin{abstract}
Phytochemicals may protect cellular DNA by direct antioxidant effect or modulation of the DNA repair activity. We investigated the repair activity towards oxidised DNA in human mononuclear blood cells (MNBC) in two placebo-controlled antioxidant intervention studies as follows: (1) wellnourished subjects who ingested $600 \mathrm{~g}$ fruits and vegetables, or tablets containing the equivalent amount of vitamins and minerals, for $24 \mathrm{~d}$; (2) poorly nourished male smokers who ingested $500 \mathrm{mg}$ vitamin C/d as slow- or plain-release formulations together with $182 \mathrm{mg}$ vitamin E/d for 4 weeks. The mean baseline levels of DNA repair incisions were 65.2 (95\% CI 60.4, 70.0) and 86.1 (95\% CI 76.2, 99.9) among the male smokers and well-nourished subjects, respectively. The male smokers also had high baseline levels of oxidised guanines in MNBC. After supplementation, only the male smokers supplemented with slow-release vitamin C tablets had increased DNA repair activity $(27(95 \%$ CI 12,41$) \%$ higher incision activity). These subjects also benefited from the supplementation by reduced levels of oxidised guanines in MNBC. In conclusion, nutritional status, DNA repair activity and DNA damage are linked, and beneficial effects of antioxidants might only be observed among poorly nourished subjects with high levels of oxidised DNA damage and low repair activity.
\end{abstract}

DNA repair: Oxidatively damaged DNA: Phytochemicals: Vitamin C: Vitamin E

Cellular DNA may be protected against oxidation by antioxidants, and oxidised DNA lesions are removed by several repair systems such as base excision repair, nucleotide excision repair and mismatch repair that have overlapping specificity and may interact or function as back-up systems ${ }^{1}$. Low activity of DNA repair towards oxidised DNA may increase the risk of cancer by increasing the accumulation of errors in the genome. It has been reported that low repair activity towards oxidised DNA is associated with increased risk of cancer in case-control studies, although this could be due to reverse causality ${ }^{2,3}$. The assessment of DNA damage has been widely discussed and evaluated in dietary intervention studies, whereas assays for the assessment of DNA repair are few and data are limited ${ }^{4}$.

In principle there are two different approaches to measure DNA repair activity in cells. Lesions can be introduced in cellular DNA and the repair activity is assessed as the removal of lesions during a subsequent incubation period. The most popular type of repair activity measured by the single cell gel electrophoresis (comet) assay has been the measurement of rejoining of strand breaks after ex vivo exposure to clastogens such as $\mathrm{H}_{2} \mathrm{O}_{2}$ or ionising radiation. Although these assays for DNA repair activity are simple, they suffer from the drawback that the genotoxic exposure may damage the repair proteins and initiate the process of programmed cell death (apoptosis). Moreover, strand breaks are generated in cultured lymphocytes as a result of exposure to atmospheric $\mathrm{O}_{2}$ and they can also accumulate as a consequence of poor repair activity. The validity of repair assays based on the rejoining of strand breaks in antioxidant intervention studies has been questioned because they cannot distinguish between rejoining of strand breaks and ex vivo scavenging effects by antioxidants 5 . These problems can be overcome by assays where extracts of cells are incubated with substrate DNA containing a defined number of lesions. Recently, a novel version of the comet assay was developed for the measurement of oxoguanine repair activity of cell extracts using substrate nuclei treated with the Ro19-8022 photosensitiser and white light ${ }^{6}$. This photosentiser generates 8-oxo-7,8-dihydro-2'-deoxyguanosine (8-oxodG) and very few strand breaks ${ }^{7,8}$. The repair activity is measured as the number of incisions that are generated during the incubation. This approach has been used in a few studies and indicates that dietary antioxidants can alter DNA repair activity ${ }^{9-11}$. The glycosylase enzymes incise at the sites of oxidised bases, leaving apurinic/apyrimidinic sites that are converted into breaks in the assay. The repair activity of Ro19-8022-damaged

Abbreviations: FPG, formamidopyrimidine DNA glycosylase; MNBC, mononuclear blood cells; OGG1, oxoguanine glycosylase 1; 8-oxodG, 8-oxo-7,8-dihydro$2^{\prime}$-deoxyguanosine.

* Corresponding author: Dr Peter Møller, fax +45 353276 86, email p.moller@pubhealth.ku.dk 
DNA is believed to mainly represent oxoguanine glycosylase 1 $(\mathrm{OGG} 1)^{6}$, whereas nei-endonuclease VIII-like (for example, NEIL1) glycosylase and nucleotide excision repair enzymes probably have little contribution to the overall repair phenotype. The aim of the present study was to investigate if fruit and vegetable intake or antioxidant supplementation modulate the oxoguanine repair activity in mononuclear blood cells (MNBC) of human subjects. The reliability of the repair assay was assessed in liver homogenate tissues of wild-type and $O g g 1$ knockout mice.

\section{Materials and methods}

We investigated the DNA repair activity of cryopreserved MNBC from two antioxidant intervention studies that have been described in detail previously ${ }^{12-14}$. The characteristics of the subjects enrolled in the two studies are outlined in Table 1. The level of oxidised purines was measured as formamidopyrimidine DNA glycosylase (FPG)-sensitive sites by the comet assay; these lesions are mainly represented by 8-oxodG and ring-opened purine lesions.

\section{Characteristics of study 1 - 'six-a-day' study}

The 'six-a-day' study was a parallel placebo-controlled intervention study in which forty-three subjects were randomised into three groups ingesting an energy-balanced basal diet free from fruits, vegetables and antioxidants, and supplemented with (1) $600 \mathrm{~g}$ fruits and vegetables, (2) tablets containing the corresponding amounts of vitamins and minerals, or (3) placebo tablets. The study is best characterised as a combined depletion and supplementation study. Blood and urine samples were collected at baseline (before) and at days 9, 16 and 24 of the supplementation. Post-intervention samples were obtained 4 weeks after the intervention had ceased. The constituents of the fruit and vegetable diet and content of the tablets have been described in detail previously ${ }^{12,14}$. The samples analysed in the present study were obtained at baseline (pre-intervention), end-supplementation (day 24) and post-supplementation (day 53).

Table 1. Characteristics of subjects in the 'six-a-day' and vitamin $C$ and E studies

(Mean values and standard deviations)

\begin{tabular}{|c|c|c|c|c|}
\hline \multirow[b]{2}{*}{ Study. . } & \multicolumn{2}{|c|}{ 'Six-a-day' } & \multicolumn{2}{|c|}{$\begin{array}{c}\text { Vitamin } \mathrm{C} \\
\text { and } \mathrm{E}\end{array}$} \\
\hline & Mean & SD & Mean & SD \\
\hline Age (years) & 27 & 6 & 39 & 12 \\
\hline \multicolumn{5}{|l|}{$\operatorname{Sex}(n)$} \\
\hline Men & \multicolumn{2}{|c|}{22} & \multicolumn{2}{|c|}{48} \\
\hline Women & \multicolumn{2}{|c|}{21} & \multicolumn{2}{|c|}{0} \\
\hline Alcohol intake $(\mathrm{g} / \mathrm{d})$ & 15 & 18 & $29^{*}$ & 26 \\
\hline Smoking & \multicolumn{2}{|c|}{ Non-smokers } & \multicolumn{2}{|c|}{ Smokers } \\
\hline Baseline vitamin $C(\mu \mathrm{mol} / \mathrm{l})$ & 69 & 17 & 49 & 18 \\
\hline $\begin{array}{l}\text { Baseline level of FPG sites } \\
\text { (arbitrary units) }\end{array}$ & $37 \dagger$ & 24 & $50 \ddagger$ & 49 \\
\hline
\end{tabular}

FPG, formamidopyrimidine DNA glycosylase.

*Assuming that one drink contains $16 \mathrm{~g}$ alcohol.

† Reported in Møller et al. ${ }^{(12)}$ and Dragsted et al. ${ }^{(14)}$

$\ddagger$ Reported in Møller et al. ${ }^{(13)}$.
The subjects enrolled in the study had a high baseline plasma concentration of vitamin $\mathrm{C}$. The concentration of plasma vitamin $\mathrm{C}$ decreased dramatically in the placebo group (the mean concentration of vitamin $\mathrm{C}$ was $21 \mu \mathrm{mol} / \mathrm{l}$ at the end of the supplementation). The profile of carotenoids was somewhat more complex; the plasma lycopene concentration only increased in the group that ingested $600 \mathrm{~g}$ fruits and vegetables/d, whereas the plasma $\beta$-carotene concentration increased the most in the group of subjects receiving tablets ${ }^{14}$.

\section{Characteristics of study 2 - vitamin C and E study}

The vitamin $\mathrm{C}$ and $\mathrm{E}$ study was designed as parallel, blinded, placebo-controlled investigation with forty-eight male smokers randomised into three groups as follows: (1) tablets with plain-release formulation of vitamin $C(2 \times 250 \mathrm{mg} / \mathrm{d})$ and vitamin $\mathrm{E}(2 \times 91 \mathrm{mg} / \mathrm{d})$; (2) tablets with slow-release formulation of vitamin $\mathrm{C}(2 \times 250 \mathrm{mg} / \mathrm{d})$ and vitamin $\mathrm{E}$ $(2 \times 91 \mathrm{mg} / \mathrm{d})$; (3) placebo. Whereas the content of vitamin $\mathrm{C}$ in the tablets is identical, ingestion of the tablets yields pharmacokinetically different variables due to the differences in release of vitamin $\mathrm{C}$ (for example, there is less fluctuation of the plasma concentration by ingestion of the tablets with slow-release formulation of vitamin $\mathrm{C}$ as compared with the plain-release tablets). On the contrary, the different formulations of the tablets have little pharmacokinetic effect on the plasma concentration of vitamin $\mathrm{E}^{15}$. The subjects ingested tablets daily for 4 weeks. The samples analysed in the present study were obtained at baseline (presupplementation) and at the end of the supplementation (end-supplementation).

\section{Measurement of DNA repair activity}

The validation of the repair assay was assessed in liver extracts from wild-type and $\mathrm{Ogg} \mathrm{I}^{-1-}$ mice. Afterwards, the DNA repair activity was determined in MNBC of the two intervention studies. Assessment of DNA repair incisions was analysed by the comet assay as described by Collins et $a .^{6}$, with modifications as described below.

\section{Preparation of cells with substrate nuclei}

We used A549 lung epithelial cells as substrate nuclei (American Type Culture Collection, Manassas, VI, USA). These were washed twice with PBS before treatment. The A549 cells were treated with a $1 \mu \mathrm{M}$ solution of the Ro19-8022 photosensitiser (a gift from Hoffmann-La Roche, Basel, Switzerland) dissolved in PBS, and irradiated for $4 \mathrm{~min}$ at $33 \mathrm{~cm}$ from two $500 \mathrm{~W}$ halogen lamps. The irradiation of the cell suspension was carried out on ice to avoid heating of the solution. After the treatment, cells were centrifuged at $700 \mathrm{~g}$ for $15 \mathrm{~min}$ to remove the photosensitiser, washed in RPMI-1640 medium (Gibco RBL, Grand Island, NY, USA) and centrifuged at $400 \mathrm{~g}$ for $15 \mathrm{~min}$. The pellet was re-suspended in freezing medium (50\% fetal bovine serum (Gibco RBL), $40 \%$ RPMI-1640 medium and $10 \%$ dimethyl sulfoxide) to a concentration of $3 \times 10^{6}$ cells $/ \mathrm{ml}$ and cryopreserved in small samples at $-80^{\circ} \mathrm{C}$. 


\section{Preparation of mouse liver extract}

Extracts of livers were obtained by placing the tissue into a stainless-steel cylinder and by use of a plunger forcing it through a sieve in one end of the cylinder $(0.5 \mathrm{~cm}$ diameter, mesh size $0.4 \mathrm{~mm}$ ), while the cylinder was submerged in $2 \mathrm{ml}$ ice-cold buffer A (45 mM-HEPES, $0.4 \mathrm{M}-\mathrm{KCl}, 1 \mathrm{~mm}-$ EDTA, $0 \cdot 1 \mathrm{mM}$-dithiothreitol, $10 \%$ glycerol, adjusted with $\mathrm{KOH}$ to $\mathrm{pH} \mathrm{7.8)} \mathrm{according} \mathrm{to} \mathrm{the} \mathrm{procedure} \mathrm{described} \mathrm{by}$ Møller et al. ${ }^{16}$. Subsequently, the extracts were cryopreserved at $-80^{\circ} \mathrm{C}$. The $O g g 1^{-1-}$ mouse liver was a cryopreserved sample used in a previous study ${ }^{17}$. On the day of the experiment, samples of the cryopreserved samples were thawed and processed as described for MNBC.

\section{Preparation of cell extract from human mononuclear blood cells}

The same isolation procedure of MNBC was used in the 'sixa-day' and vitamin C and E studies. MNBC from venous blood were isolated in cell preparation tubes and cryopreserved in freezing medium $(50 \%$ fetal bovine serum, $40 \%$ RPMI-1640 medium and $10 \%$ dimethylsulfoxide). The cryopreserved cell samples were thawed and $5 \mathrm{ml}$ of a 3 -fold diluted extraction buffer A were added. The number of cells was ascertained and the samples centrifuged at $700 \mathrm{~g}$ for $5 \mathrm{~min}$ at $4^{\circ} \mathrm{C}$. As much as possible of the supernatant fraction was removed. The pellet was re-suspended by vigorously tapping the tube and $20 \mu \mathrm{l}$ buffer A was added for each $10^{6}$ cells. The suspended cells were divided into $50 \mu \mathrm{l}$ samples and frozen at $-80^{\circ} \mathrm{C}$. This procedure of MNBC extract generation deviated from the original procedure ${ }^{6}$, but we obtained similar incision activity in control experiments where we compared the two extract isolation procedures (results not shown).

\section{In vitro repair incubation}

Frozen samples of MNBC extracts were thawed and $12 \mu 11 \%$ Triton X-100 in buffer A were added. The lysate was subsequently centrifuged at $13500 \mathrm{rpm}$ for $5 \mathrm{~min}$ at $4^{\circ} \mathrm{C}$ to remove cell debris. The supernatant fraction was mixed with 4 volumes buffer B (40 mM-HEPES, $0.1 \mathrm{M}-\mathrm{KCl}$, $0.5 \mathrm{~mm}$-EDTA, bovine serum albumin $(0.2 \mathrm{mg} / \mathrm{ml}), \mathrm{pH} 8)$ and kept on ice until use. Samples of cells with substrate nuclei were thawed, mixed with low-melting-point gel ( $0.75 \%$; Sigma-Aldrich, Brøndby, Denmark) and applied on $85 \times 100 \mathrm{~mm}$ GelBond ${ }^{\circledR}$ films (Cambrex, Medinova Scientific A/S, Hellerup, Denmark). Each GelBond consisted of eight $19 \times 23 \mathrm{~mm}$ agarose gels. The GelBonds were immersed in lysis solution $\left(2.5 \mathrm{M}-\mathrm{NaCl}, 0 \cdot 1 \mathrm{mM}-\mathrm{Na}_{2}\right.$ EDTA, $10 \mathrm{~mm}$-tri (hydroxymethyl)-aminomethane (Tris), $1 \%$ Triton X-100, $\mathrm{pH} 10)$ for $1 \mathrm{~h}$ at $4^{\circ} \mathrm{C}$. Then the GelBonds were washed three times $(5 \mathrm{~min}$ each) in buffer B. Cell extract $(60 \mu \mathrm{l})$ was added to each gel and incubated for $20 \mathrm{~min}$ at $37^{\circ} \mathrm{C}$ in a humid box. Control gels were incubated for $20 \mathrm{~min}$ with $60 \mu \mathrm{l}$ of a control solution consisting of Triton X-100 and buffer B (without lymphocyte extract). The GelBonds were then placed in a horizontal electrophoresis tank and immersed in fresh solution $\left(0.3 \mathrm{M}-\mathrm{NaOH}, 1 \mathrm{M}-\mathrm{Na}_{2}\right.$ EDTA) for $40 \mathrm{~min}$, before electrophoresis at $25 \mathrm{~V}(0.83 \mathrm{~V} / \mathrm{cm})$ and $300 \mathrm{~mA}$ for 20 min. After neutralisation with $0.4 \mathrm{M}$-Tris- $\mathrm{HCl}(\mathrm{pH} \mathrm{7.5)}$ cells were placed in $96 \%$ ethanol for $1.5 \mathrm{~h}$ or overnight. The nuclei were visualised in an Olympus fluorescence microscope at $40 \times$ magnification and two gels of 100 nuclei were scored as degrees of migration in classes $0-4$ after staining with $50 \mu \mathrm{l}$ YOYO-1 (Molecular Probes, Leiden, The Netherlands) in PBS buffer. The repair activity of the MNBC extract was determined as the difference in score (arbitrary units) between parallel gels incubated with extract and control solution.

\section{Statistics}

Differences in the baseline values of DNA repair phenotype of the two datasets were tested by ANOVA with unequal variance of groups because of lack of homogeneity of the variance (Levene's test). Effects of the intervention were tested by one-factor repeated-measurements ANOVA of two groups (placebo group $v$. active group). Since the data from the placebo groups were tested twice against the active groups, the statistical significance was accepted at $P<0.025$ after Bonferroni correction for multiple tests. Analysis of normal distribution of residuals was tested by the ShapiroWilk $\mathrm{W}$ test. The relationship between DNA repair incision activity and FPG sites in baseline samples was analysed by linear regression with $P<0.05$ as the significance level. The statistical analysis was carried out in STATISTICA version 5.5 for Windows (Statsoft, Inc., Tulsa, OK, USA).

\section{Results}

The DNA repair assay was implemented with several modifications compared with the original protocol, but we essentially observed similar time curves of the incision activity as reported previously, i.e. an initial linear increase of incisions followed by a plateau ${ }^{6}$. We found that the most reliable incision activity was observed after $20 \mathrm{~min}$ incubations, based on considerations that the number of incisions should be as high as possible before the plateau is reached (results not shown). Fig. 1 outlines the results from experiments of dilutions of enzyme extract from the liver of mice. The protein concentration of the undiluted liver extract was $4 \mathrm{mg} / \mathrm{ml}$, which was lower than that used for MNBC (about $20 \mathrm{mg} / \mathrm{ml}$ ) because we assumed higher repair activity of the hepatocytes compared with MNBC. The 10-fold dilution of the wild-type liver extract reduced the incision activity to $43(95 \% \mathrm{CI}$

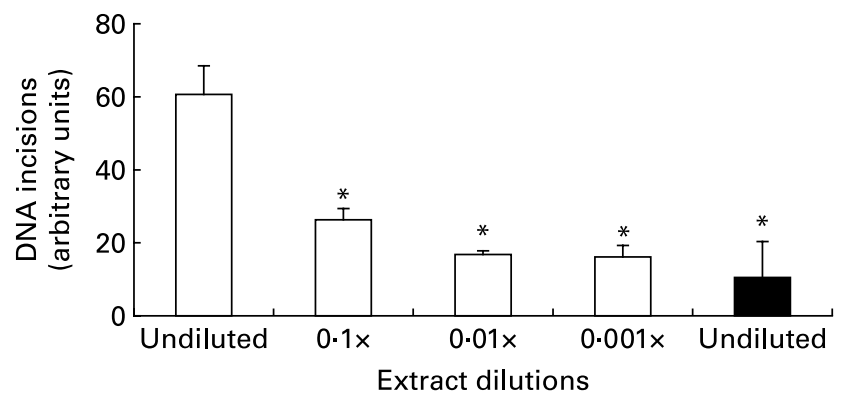

Fig. 1. DNA repair incisions of wild-type $(\square)$ and $O g g 1^{-1-}(\square)$ mouse liver extract. Values are means of three independent experiments, with standard errors represented by vertical bars. * Mean value was significantly different from that of the undiluted wild-type liver extract $(P<0.001$; ANOVA). 
$21,65) \%$. The repair incision activity of the $O g g 1^{-1-}$ mouse liver extract was very low, i.e. $17(95 \%$ CI 0,39$) \%$ compared with the undiluted wild-type mouse liver sample, but it was not significantly lower than the 100-fold and 1000-fold diluted wild-type mouse liver extract samples.

The results of the baseline values in the two intervention studies are shown in Fig. 2. As can be seen, the distributions are quite different $(P<0.001$; Levene's test $)$. The values of the poorly nourished smokers in the vitamin $\mathrm{C}$ and $\mathrm{E}$ study are less scattered than the results from well-nourished subjects in the 'six-a-day' study, although there was difference in repair incisions between the placebo and slow-release groups at baseline $(P<0.05$; one-factor ANOVA). The mean repair incision activity was higher for the subjects in the "six-aday' study (mean $86 \cdot 1 ; 95 \%$ CI $76 \cdot 2,99.9$ ) than in the vitamin $\mathrm{C}$ and E study (mean 65.2; $95 \%$ CI 60.4, 70.0; $P<0.001$; ANOVA for groups with unequal variances). The residuals of this analysis did not deviate from a normal distribution $(P=0 \cdot 12$; Shapiro-Wilk W test), indicating little unexplained variation. The subjects in the vitamin $\mathrm{C}$ and $\mathrm{E}$ study were smokers, who had higher alcohol consumption, lower plasma vitamin $\mathrm{C}$ concentration, and higher levels of FPG sites in MNBC at baseline (Table 1). Although, at group level, there appeared to be an inverse relationship between the level of DNA repair incisions and FPG sites, there was not a statistically significant linear relationship between these biomarkers in the 'six-a-day' and vitamin $\mathrm{C}$ and $\mathrm{E}$ studies $(P>0.05$; linear regression analysis).

Table 2 outlines the results of repair phenotype of MNBC extracts. The analysis of DNA repair phenotype was successful in forty-six samples of the vitamin $\mathrm{C}$ and $\mathrm{E}$ study, encompassing eighteen datasets in each of the active supplementation groups and ten subjects in the placebo group. In the 'six-a-day' study, samples from thirty-nine subjects were available and analysed, which included twelve, thirteen and fourteen subjects in the vitamins, fruit and vegetable, and placebo group, respectively. There was no significant variation in the DNA repair phenotype related to the intervention $(P>0.025$; ANOVA for repeated measurements).

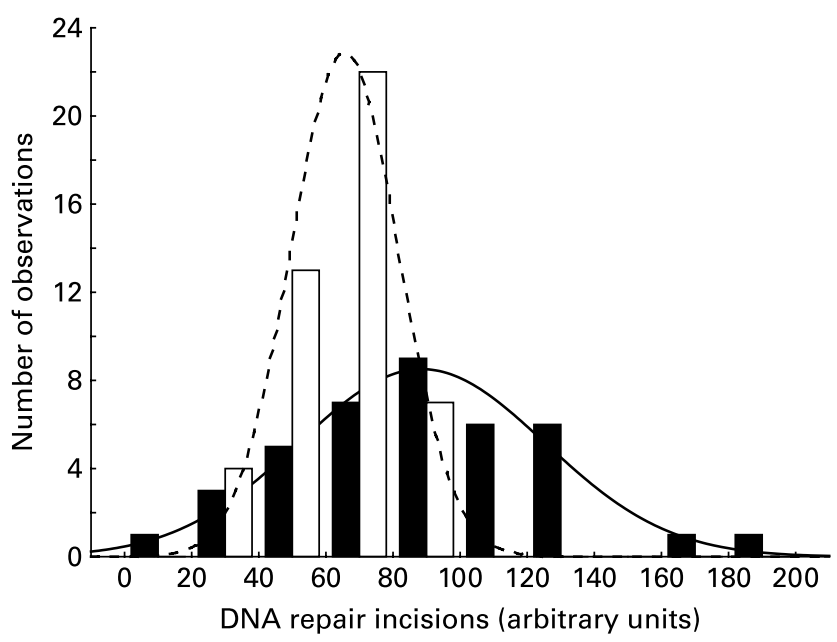

Fig. 2. Distributions of baseline DNA repair incision of mononuclear blood cell of subjects in the 'six-a-day' $(\mathbf{\square},-)$ and vitamin $C$ and $E(\square,--)$ intervention studies. The data are repair incisions measured in arbitrary units.
On the contrary, ingestion of slow-release vitamin $\mathrm{C}$ formulation for 4 weeks in heavy smokers was associated with a significantly increased repair capacity $(P<0.025$; repeatedmeasurement ANOVA), whereas there was no difference in DNA repair incisions between subjects supplemented with tablets with plain-release formulation of vitamin $\mathrm{C}$ and placebo ( $P>0.025$; repeated-measurement ANOVA). In Fig. 3, changes in DNA repair activity observed in the present study are combined with changes in FPG sites previously reported $^{13}$. The alteration of FPG sites is virtually a mirror image of the change in DNA repair.

\section{Discussion}

Oxidised DNA in cells is usually kept at a low steady-state level because the DNA repair system removes lesions from the DNA. However, during oxidative stress, the level of oxidised DNA in cells may increase because the DNA repair system cannot remove lesions with sufficient speed. Lower levels of oxidised DNA following supplementation with phytochemicals suggest that the bioactive constituents may increase the activity of the DNA repair system in addition to a direct scavenging effect of reactive oxygen species.

Methods for the assessment of DNA repair activity are scarce despite their relevance for understanding the cellular response to oxidative stress. The novel application of the comet assay for repair incision activity of cellular extracts is still relatively new and only a few groups have reported results from investigations with this method. Therefore we devoted some time to reassessing the initial assay validation carried out by Collins and co-workers, who reported that fibroblast cell cultures from $\mathrm{Oggl} 1^{-1-}$ mice had very little incision activity ${ }^{6}$. We found a dramatically reduced incision activity of the diluted wild-type extract, and 10-fold dilutions did not differ significantly from $O g g 1^{-/-}$liver extract, which had virtually no incision activity on Ro19-8022 substrate nucleoids. These results are in accordance with those reported by Collins et $\mathrm{al}^{6}{ }^{6}$ who showed virtually no incisions by fourfold dilution of lymphocyte extracts.

Reliable assays for the measurement of repair of oxidised DNA bases by human MNBC cell extracts have become increasingly popular in recent years. However, investigations have mainly been carried out in small groups of subjects and high inter-individual variation can be difficult to separate from assay variation. In the present study we investigated the repair activity of MNBC extracts in two populations with different characteristics. This showed that at baseline there was not only a difference between subjects, but also differences between the groups of the population in the level of repair activity. Baseline differences in effect markers can be observed in parallel designs because of the unintentional heterogeneous randomisation of subjects. We do not believe that it affects the interpretation of the data because we have not selected participants with low incision activity that otherwise could lead to a regression towards the mean phenomenon. In addition, the data obtained in the vitamin $\mathrm{C}$ and $\mathrm{E}$ study are not unreasonably low; for example, we have previously found incision activities in the range of 50 arbitrary units in young and healthy subjects ${ }^{18}$. However, problems with baseline differences in biomarkers can be alleviated by the use of cross-over designs, but this type of design suffers from other problems such as carry-over effects, 
Table 2. DNA repair incisions in mononuclear blood cell extracts of subjects in the 'six-a-day' and vitamin $\mathrm{C}$ and $\mathrm{E}$ studies* (Mean values with their standard errors)

\begin{tabular}{|c|c|c|c|c|c|c|c|}
\hline \multirow[b]{3}{*}{ Study } & \multicolumn{7}{|c|}{ DNA repair incisions (arbitrary units) } \\
\hline & \multicolumn{2}{|c|}{ Pre-supplement } & \multicolumn{2}{|c|}{ End-supplement } & \multicolumn{2}{|c|}{ Post-supplement } & \multirow[b]{2}{*}{$P \dagger$} \\
\hline & Mean & SEM & Mean & SEM & Mean & SEM & \\
\hline \multicolumn{8}{|l|}{ ‘Six-a-day' } \\
\hline Fruit and vegetables $(n 13)$ & $88 \cdot 1$ & $9 \cdot 6$ & $82 \cdot 4$ & 8.9 & 91.9 & $10 \cdot 0$ & 0.585 \\
\hline Vitamins $(n 12)$ & $77 \cdot 1$ & $14 \cdot 2$ & $78 \cdot 6$ & 11.5 & $72 \cdot 6$ & 11.5 & 0.866 \\
\hline Placebo $(n 14)$ & 97.4 & 11.5 & 91.7 & $11 \cdot 1$ & 89.5 & $10 \cdot 0$ & - \\
\hline \multicolumn{8}{|l|}{ Vitamin $\mathrm{C}$ and $\mathrm{E}$} \\
\hline $\begin{array}{l}\text { Vitamin } C \text { (slow-release formulation) } \\
\text { and vitamin } \mathrm{E}(n 18)\end{array}$ & $58 \cdot 3$ & $3 \cdot 3$ & $74 \cdot 0$ & $5 \cdot 3$ & \multicolumn{2}{|c|}{ ND } & 0.024 \\
\hline $\begin{array}{l}\text { Vitamin } C \text { (plain-release formulation) } \\
\text { and vitamin } \mathrm{E}(n \text { 18) }\end{array}$ & $67 \cdot 7$ & 3.8 & $72 \cdot 6$ & 4.6 & \multicolumn{2}{|c|}{ ND } & 0.333 \\
\hline Placebo $(n 10)$ & 73.0 & $5 \cdot 1$ & $71 \cdot 6$ & 4.6 & \multicolumn{2}{|c|}{ ND } & - \\
\hline
\end{tabular}

Pre-supplement, baseline; end-supplement, end of the supplementation period; post-supplement, 4 weeks after the end of the supplementation; ND, not determined.

${ }^{*}$ DNA repair incisions are obtained as the difference in score (arbitrary units) of substrate samples (i.e. A549 cells exposed to $1 \mu \mathrm{M}-\mathrm{Ro} 19-8022$ and white light) treated with mononuclear blood cell extract and buffer. The $P$ values correspond to statistical analysis of repeated-measurement analysis that tests the difference in changes over time between the treatment and placebo groups.

†Effects of the intervention were tested by one-factor repeated-measurements ANOVA with $P<0.025$ as the level of statistically significant effect.

and systematic variation over time can be particularly troublesome. The overall mean of baseline repair activity for both datasets was 76.7 (SD 29.6) with a corresponding CV of $39 \%$, but the data are not normally distributed. This is similar to the CV $(34 \%)$ reported in a study on 375 subjects $^{19}$, whereas another study among 244 subjects reported a CV in the range of $100 \%^{20}$. The repair incision activity in these subjects was reported to correlate weakly and positively with age $\mathrm{e}^{19}$ or not being age dependent ${ }^{20}$. Sex and smoking habit were not reported to affect DNA repair activity towards oxidised bases, whereas polymorphisms in the $O G G 1$ and $X P A$ genes affected the repair incision activity ${ }^{19,20}$. This indicates that that age, sex and smoking are not strong determinants for the repair incision activity and the differences we have observed between the subjects in the 'six-a-day' and vitamin $C$ and $E$ studies could be due to other lifestyle and genetic variables. It should be emphasised that the repair activity of the two datasets were analysed at the same time, and the difference cannot be attributed to variation in the analysis over time. The 'six-a-day' samples had been stored for a longer time ( 6 years) than the samples from the vitamin $\mathrm{C}$ and $\mathrm{E}$ study (4 years). A recent study did not show decreased repair activity, determined as cleavage of 8-oxodGcontaining oligonucleotides, in samples after storage for 3 years $^{21}$. Clearly, further studies are warranted that assess the stability of repair activity during storage.

The effect of phytochemical supplementation on DNA damage has been investigated in more than 100 studies, whereas few studies on repair activity are available ${ }^{4}$. Increased DNA repair activity was observed after supplementation with kiwi fruits, and this was accompanied by decreased levels of oxidised DNA in $\mathrm{MNBC}^{10}$. Using a different assay for repair activity, cell extract-associated incision activity of plasmid DNA treated with
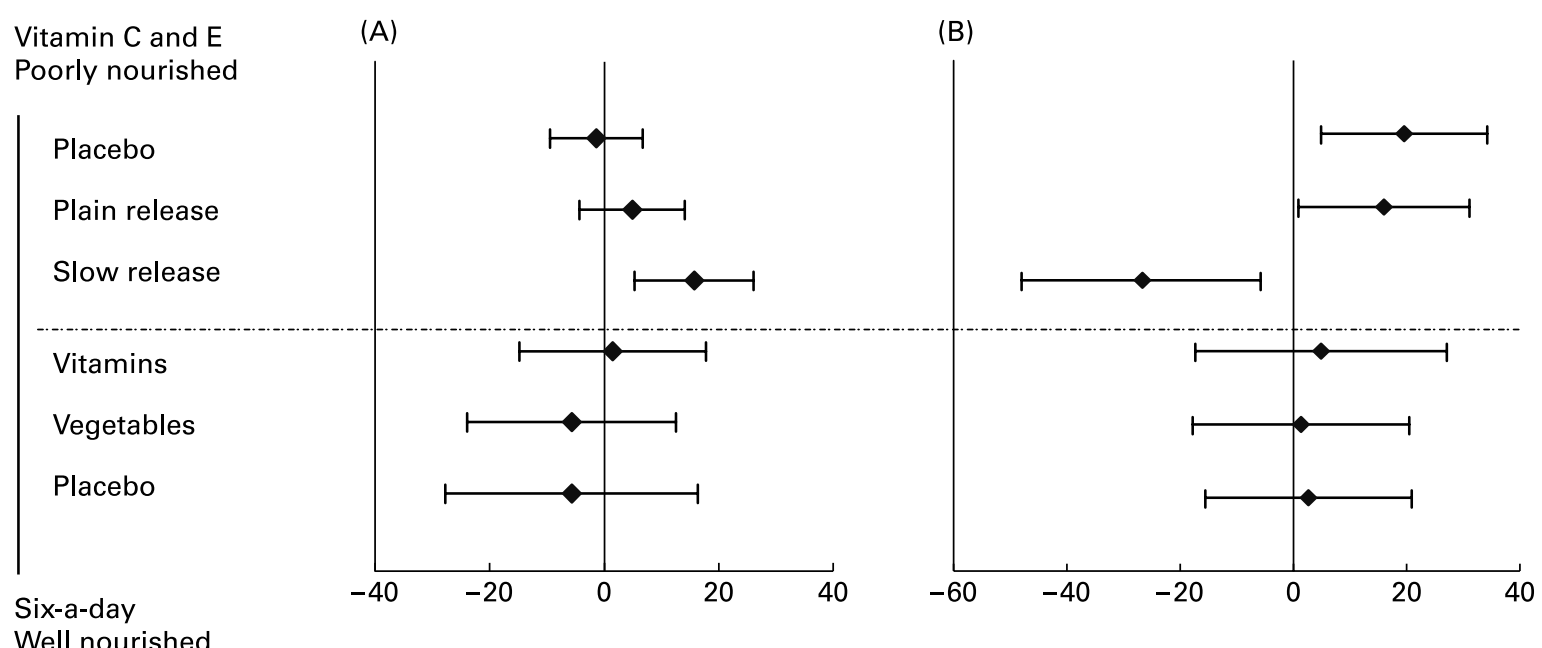

Well nourished

Fig. 3. Changes in repair activity (as difference of incisions in arbitrary units) (A) and formamidopyrimidine DNA glycosylase (FPG) sites (as difference in FPG sites in arbitrary units) (B) in mononuclear blood cells of subjects in the 'six-a-day' and vitamin $\mathrm{C}$ and $\mathrm{E}$ studies. In the vitamin $\mathrm{C}$ and $\mathrm{E}$ study subjects were supplemented with tablets containing $500 \mathrm{mg}$ vitamin $\mathrm{C} / \mathrm{d}$ as either a plain- or slow-release formulation together with $182 \mathrm{mg}$ vitamin E/d. The subjects in the 'six-aday' study received either $600 \mathrm{~g}$ fruits and vegetables/d or tablets containing the corresponding amounts of vitamins and minerals. Data are the differences between post- and pre-intervention. Values are means, with $95 \% \mathrm{Cl}$ represented by horizontal bars. 
methylene blue and visible light, it was indicated that ingestion of cooked carrots increased repair activity, whereas ingestion of mixed carotene tablets and tinned mandarin oranges had no effect on DNA repair activity 9 . Increased repair incisions of Ro19-8022-induced DNA damage were also observed following a 1-week supplementation with coenzyme $\mathrm{Q}_{10}$, whereas the levels of FPG sites in MNBC did not change ${ }^{11}$. Our observation that increased incision repair activity was induced by vitamin $\mathrm{C}$ supplementation corroborates well with these results, and indicates that it is possible to increase repair activity toward oxidised DNA in MNBC by supplementation with phytochemicals and antioxidants. It is all the more interesting that it was not possible to alter the repair incision activity in MNBC of the well-nourished subjects in the 'six-a-day' study. Measurements of the OGG1 mRNA levels in whole blood of the subjects were not altered because of the treatment in the present study, and the vitamin $C$ and $E$ supplementation study, although period effects were observed in both studies ${ }^{12,13,22}$. However, the data on OGG1 mRNA levels are not directly comparable with the measurements of DNA repair activity because the latter was investigated in MNBC. The unaltered incision repair activity of the subjects in the 'six-a-day' study might be explained by the short duration of the depletion period in these well-nourished subjects. The lifespan of lymphocytes, which is the major fraction of $\mathrm{MNBC}$, is usually considered to be long (probably years), although it is likely to depend on the subtype of lymphocytes. The depletion of phytochemicals in the 'six-a-day' study was only $24 \mathrm{~d}$, which is a short time compared with the lifespan of lymphocytes. Thus, it is reasonable to expect that a large fraction of the cells in the blood remained unaltered after $24 \mathrm{~d}$. A similar lack of effect was observed for antioxidant enzyme activity (including catalase, superoxide dismutase and glutathione reductase) in erythrocytes, which only have a lifespan of $120 \mathrm{~d}$, but glutathione peroxidase in the erythrocytes was significantly increased by the fruit and vegetable intervention, indicating that changes in some biomarkers over a shorter time period may take place even in cell populations which have long half-lives even without de novo protein synthesis ${ }^{14}$. It had been shown that the ex vivo sensitivity to oxidatively induced DNA damage increased in subjects with reduced antioxidant levels at baseline associated with a controlled run-in period with a diet poor in antioxidants ${ }^{23,24}$. Taken together, the data suggest that the subjects in the 'six-a-day' study might not have experienced significant oxidative stress following the $24 \mathrm{~d}$ depletion of antioxidants. Thus, the most important interpretation of these observations is that swift alterations in DNA repair enzyme activity can be observed by supplementation of antioxidants in poorly nourished subjects, whereas severe depletion of antioxidants for long periods of time might be required to observe alterations in well-nourished subjects.

In conclusion, determinants of the oxoguanine glycosylase repair phenotype encompass dietary habits, lifestyle factors and genetic differences. Subjects with poor habitual antioxidant intake may benefit from supplementation with concomitant reduction of the level of oxidised DNA in cells.

\section{Acknowledgements}

The technical assistance from Claus Nielsen and Gitte Friis is gratefully acknowledged. The present study was partly supported by ECNIS (Environmental Cancer Risk, Nutrition and Individual Susceptibility), a network of excellence operating within the European Union 6th Framework Program, Priority 5, 'Food Quality and Safety' (contract no. 513943) and the Danish Research Councils.

\section{References}

1. Dizdaroglu M (2005) Base-excision repair of oxidative DNA damage by DNA glycosylases. Mutat Res 591, 45-59.

2. Paz-Elizur T, Krupsky M, Blumenstein S, Elinger D, Schechtman E \& Livneh Z (2003) DNA repair activity for oxidative damage and risk of lung cancer. J Natl Cancer Inst 95, 1312-1319.

3. Paz-Elizur T, Ben-Yosef R, Elinger D, Vexler A, Krupsky M, Berrebi A, Shani A, Schechtman E, Freedman L \& Livneh Z (2006) Reduced repair of the oxidative 8-oxoguanine DNA damage and risk of head and neck cancer. Cancer Res 66, 11683-11689.

4. Møller P (2006) Loft S Dietary antioxidants and beneficial effect on oxidatively damaged DNA. Free Radic Biol Med 41, $388-415$.

5. Torbergsen AC \& Collins AR (2000) Recovery of human lymphocytes from oxidative DNA damage: the apparent enhancement of DNA repair by carotenoids is probably simply an antioxidant effect. Eur J Nutr 39, 80-85.

6. Collins AR, Dusinska M, Horváthová E, Munro E, Savio M \& Stetina R (2001) Inter-individual differences in repair of DNA base oxidation, measured in vitro with the comet assay. Mutagenesis 16, 297-301.

7. Pflaum M, Will O \& Epe B (1997) Determination of steadystate levels of oxidative DNA base modifications in mammalian cells by means of repair endonucleases. Carcinogenesis 18, 2225-2231.

8. Will O, Gocke E, Eckert I, Schulz I, Pflaum M, Mahler H-C \& Epe B (1999) Oxidative DNA damage and mutations induced by a polar photosensitizer, Ro19-8022. Mutat Res 435, 89-101.

9. Astley SB, Elliott RM, Archer DB \& Southon S (2004) Evidence that dietary supplementation with carotenoids and carotenoid-rich foods modulates the DNA damage:repair balance in human lymphocytes. Br J Nutr 91, 63-72.

10. Collins AR, Harrington V, Drew J \& Melvin R (2003) Nutritional modulation of DNA repair in a human intervention study. Carcinogenesis 24, 511-515.

11. Tomasetti M, Alleva R \& Collins AR (2001) In vivo supplementation with coenzyme $\mathrm{Q}_{10}$ enhances the recovery of human lymphocytes from oxidative DNA damage. FASEB $J \mathbf{1 5}$, 1425-1427.

12. Møller P, Vogel U, Pedersen A, Dragsted LO, Sandström B \& Loft S (2003) No effect of $600 \mathrm{~g}$ fruit and vegetables per day on oxidative DNA damage and repair in healthy human nonsmokers. Cancer Epidemiol Biomarkers Prev 12, 1016-1022.

13. Møller P, Viscovich M, Lykkesfeldt J, Loft S, Jensen A \& Poulsen HE (2004) Vitamin C supplementation decreases oxidative DNA damage in mononuclear blood cells of smokers. Eur J Nutr 43, 267-274.

14. Dragsted LO, Pedersen A, Hermetter A, et al. (2004) The 6-aday study: effects of fruit and vegetables on markers of oxidative stress and antioxidative defense in healthy nonsmokers. Am J Clin Nutr 79, 1060-1072.

15. Viscovish M, Lykkesfeldt J \& Poulsen HE (2004) Vitamin C pharmacokinetics of plain and slow release formulations in smokers. Clin Nutr 23, 1043-1050.

16. Møller P, Wallin H, Vogel U, Autrup H, Risom L, Hald MT, Daneshvar B, Dragsted LO, Poulsen HE \& Loft S (2002) Mutagenecity of 2-amino-3-methylimidazo(4,5-f)quinoline in 
colon and liver of Big Blue rats: role of DNA adducts, strand breaks and oxidative stress. Carcinogenesis 23, 1379-1385.

17. Risom L, Dybdahl M, Møller P, Wallin H, Haun T, Vogel U, Klungland A \& Loft S (2007) Repeated inhalations of diesel exhaust particles and oxidatively damaged DNA in young oxoguanine DNA glycosylase (OGG1) deficient mice. Free Rad Res 41, 172-181.

18. Bräuner EV, Forchhammer L, Møller P, Simonsen J, Glasius M, Wåhlin P, Raaschou-Nielsen O \& Loft S (2007) Exposure to ultrafine particles from ambient air and oxidative stress-induced DNA damage. Environ Health Perspect 115, 1177-1182.

19. Dusinska M, Dzupinkova Z, Wsolova L, Harrington V \& Collins AR (2006) Possible involvement of XPA in repair of oxidative DNA damage deduced from analysis of damage, repair and genotype in a human population study. Mutagenesis 21, 205-211.

20. Vodicka P, Stetina R, Polakova V, et al. (2007) Association of DNA repair polymorphisms with DNA repair functional outcomes in healthy human subjects. Carcinogenesis 28, 657-664.
21. Paz-Elizur T, Elinger D, Leitner-Dagan $\mathrm{Y}$, Blumenstein $\mathrm{S}$, Krupsky M, Berrebi A, Schechtman E \& Livneh Z (2007) Development of an enzymatic DNA repair assay for molecular epidemiology studies: distribution of OGG activity in healthy individuals. DNA Repair (Amst) 6, 45-60.

22. Vogel U, Møller P, Dragsted LO, Loft S, Pedersen A \& Sandström B (2002) Inter-individual variation, seasonal variation and close correlation of $O G G 1$ and ERCC1 mRNA levels in full blood from healthy volunteers. Carcinogenesis 23, 1505-1509.

23. Lean MEJ, Noroozi M, Kelly I, Burns J, Talwar D, Sattar N \& Crozier A (1999) Dietary flavonols protect diabetic human lymphocytes against oxidative damage to DNA. Diabetes 48 , $176-181$.

24. Riso P, Visioli F, Erba D, Testolin G \& Porrini M (2004) Lycopene and vitamin $\mathrm{C}$ concentrations increase in plasma and lymphocytes after tomato intake. Effects on cellular antioxidant protection. Eur J Clin Nutr 58, 1350-1358. 